\title{
STRESS DISTRIBUTION AROUND TITANIUM-ZIRCONIUM NARROW-DIAMETER IMPLANTS RETAINING MANDIBULAR OVER DENTURES WITH NOVALOC VERSUS LOCATOR ATTACHMENT SYSTEMS. A THREE-DIMENSIONAL FINITE ELEMENT ANALYSIS
}

\author{
Eatemad R. Taha *
}

\begin{abstract}
Statement of the problem: The use of narrow diameter implant to retain an implant overdenture could be the treatment of choice to restore resorbed mandibular ridge, however its success or failure depends on the amount of stresses transferred to the surrounding bone via the selected attachment system. The goal of this study was to evaluate the stress distribution around two narrow- diameter titanium-zirconium implants retaining mandibular overdenture with novel Novaloc attachment system in comparison with traditional locator attachment using $3 \mathrm{D}$ finite element analysis
\end{abstract}

Materials and methods: Two 3D finite element models were prepared simulating completely edentulous mandibular ridge with complete overdentures supported by two narrow diameter implants in the canine region. Model 1, represented implants with locator attachment while Model 2, represented implants with Novaloc attachment. The models' components were created on a commercial CAD/CAM package then imported to finite element software. Load of $100 \mathrm{~N}$ was applied on molar area of the mandible vertically and oblique Load of $50 \mathrm{~N}$ at $30^{\circ}$ and $45^{\circ}$ angle.

Results: Within the limitations of this research, similar deformations and stresses distributions were reported in the bone and implant complex with a little more stresses in the Novaloc system. All values found were within acceptable physiological limits of the studied parts. Stress received by the PEEK matrix of the Novaloc attachment was significantly less than that of the locator nylon cap.

Conclusion: Within the limitations of this in-vitro study it may be concluded that locator attachments may provide little less stress on the bone and implant complex in implant retained overdenture than did the Novaloc attachment. However, the lifetime of the flexible caps may be longer for Novaloc system in comparison to locator ones.

KEY WORDS: Stress distribution, Titanium-Zirconium implants, implant overdenture, Novaloc, locator attachment, PEEK, Finite element method.

* Associate Professor, Removable Prosthodontics Department, Faculty of Oral \& Dental Medicine, Ahram Canadian University, Egypt. 


\section{INTRODUCTION}

Currently, rehabilitation of edentulous arches with implant-supported or implant-retained overdentures is considered a predictable and successful treatment modality. It provide better retention and stability, improving function and esthetics as well as preserving the residual bone, especially in the mandible..$^{1-3}$

Numerous longitudinal studies, have approved that implant-supported overdentures provide satisfactory results with only two mandibular implants. ${ }^{4-6}$ Further, it is generally accepted that two implant-supported overdenture treatment is the classical standard of care for an edentulous mandible, rather than conventional complete denture. ${ }^{7,8}$

Titanium has been used successfully as an implant material due to its excellent biocompatibility and mechanical properties. However, when used as reduced-diameter implants, the risk of fracture is increased. ${ }^{9}$ However dental implants made from Titanium zirconium alloys with 13\%-17\% zirconium have better mechanical properties, such as increased tensile and the fatigue strength, compared to pure titanium. Therefore, it is used in production of narrow diameter implants and implant components that can be subjected to high strains..$^{10,11}$ In addition, titanium-zirconium alloy showing obvious decrease in ion release, which explain its more inert and biocompatible behavior in comparison with commercially pure Titanium. Roxolid implants were developed recently by Straumann, which made from a high-performance alloy composed of $85 \%$ titanium and, $15 \%$ zirconium. This binary TiZr alloys have been shown to achieve good osseointegration and high success rates both in animal and in clinical studies. ${ }^{12-15}$

Crestal bone-height changes, soft tissue parameters between small-diameter implants made of titanium/zirconium (TiZr) alloy or of Grade IV titanium (Ti), were evaluated in edentulous mandibles restored with removable overdentures. Implant suc- cess and survival were also assessed similar outcomes were found between Ti Grade IV and TiZr implants, where no significant differences were found between the two implant types for bone-level change, soft tissue parameters, survival and success. ${ }^{16}$

Various commercially available attachments could be used to retain an implant overdenture, i.e., stud, bar, magnetic and telescopic attachment. Stud attachments are classified into resilient and non-resilient attachments based on its behavior during function. Stud attachments include o-ring, ball, ERA and locator attachments. ${ }^{17}$ The locator attachment system is a resilient, non-splinted, low profile attachment. Its short profile distance was considered an advantageous and was related to the reduction of load transfer to the implant through reducing the length of the lever arm. In addition, Locator attachment system has self-aligning feature and has dual retention (inner and outer).It come in different colors (white, pink and blue) and each has different retentive value. ${ }^{18-20}$

Novel stud-type attachment called Novaloc was introduced in 2016, based on mechanical retention from a polyetheretherketone (PEEK) matrix on a cylindrical patrix, that may be more resistant to wear than the nylon used in other attachment systems. The abutments also receive an amorphous diamond-like carbon surface coating that minimizes roughness and is intended to enhance resistance of the attachment components. The Novaloc $\AA$ attachment however demands very little space, since the female part is only $2.3 \mathrm{~mm}$ high and $5.5 \mathrm{~mm}$ in diameter. Thus, the Novaloc $\AA$ attachment is one of the smallest suitable attachments available. An in vitro study was conducted to evaluate longterm retention of PEEK matrices compared to the traditional Locator system and shows promising results. ${ }^{21}$

For success of implant-retained overdentures, it is important to control stresses transferred to the 
bone surrounding the implants through different prosthesis design, type, material, occlusion, and attachment configuration. The correct selection of attachment system is critical for uniform load distribution between the implant and the underlying residual alveolar ridge to minimize its resorption. ${ }^{22,23}$

To evaluate the stress distribution in the periimplant bone, Different methods are used as photoelastic analysis, strain gauge, and finite element analysis. 3D Finite Element Analysis (FEA) is a precise method for evaluating the amount and pattern of stress distribution in dental structures which has many advantages over other methods. FEA is a reproducible, repeatable and non-invasive technique that could easily simulate any biological condition in pre-, intra-, and postoperative stages. The technique is applicable to linear and nonlinear as well as solid and fluid structural interactions..$^{24,25}$ Many authors have used FEA to study the influence of different attachment on the bone integrity of implant-overdenture..$^{26-36}$

Based on this finding, the aim of the present study was to evaluate the stress distribution around narrow- diameter titanium- zirconium implants retaining mandibular overdenture with novel Novaloc attachment system in comparison with traditional locator attachment using $3 \mathrm{D}$ finite element analysis.

\section{MATERIALS AND METHODS}

The current finite element analysis simulates a clinical situation where an edentulous mandible was restored with an implant retained overdenture on two implants placed in the canine region. Based on previous studies ${ }^{27-29}$, two finite element models were prepared specially for this study as follows:

1. Model 1, represented implants with locator attachments

2. Model 2, represented implants with Novaloc attachments.

The finite element models' components as the overdenture, mucosa, caps, attachments, cortical and cancellaus bones were created on "Autodesk Inventor" Version 8 (Autodesk Inc., San Rafael, CA, USA), then exported as SAT files. These components were assembled in ANSYS environment (ANSYS Inc., Canonsburg, PA, USA). Where, the designs of the implant and of the attachment systems were taken from the manufacturer data. The system analyzed in this investigation consisted of the commonly available root form threaded dental implant of $3.3 \mathrm{~mm}$ wide, composed of Ti-Zr alloy (Roxolid Standard Tissue Level implant, Straumann) with a length of $12 \mathrm{~mm}$. The locator attachment (Zest Anchors, Escondido, CA) is commonly used, while Novaloc (Valoc, Möhlin, Switzerland), is a new novel model with PEEK matrix insert and carboncoated abutment (Figure 1).

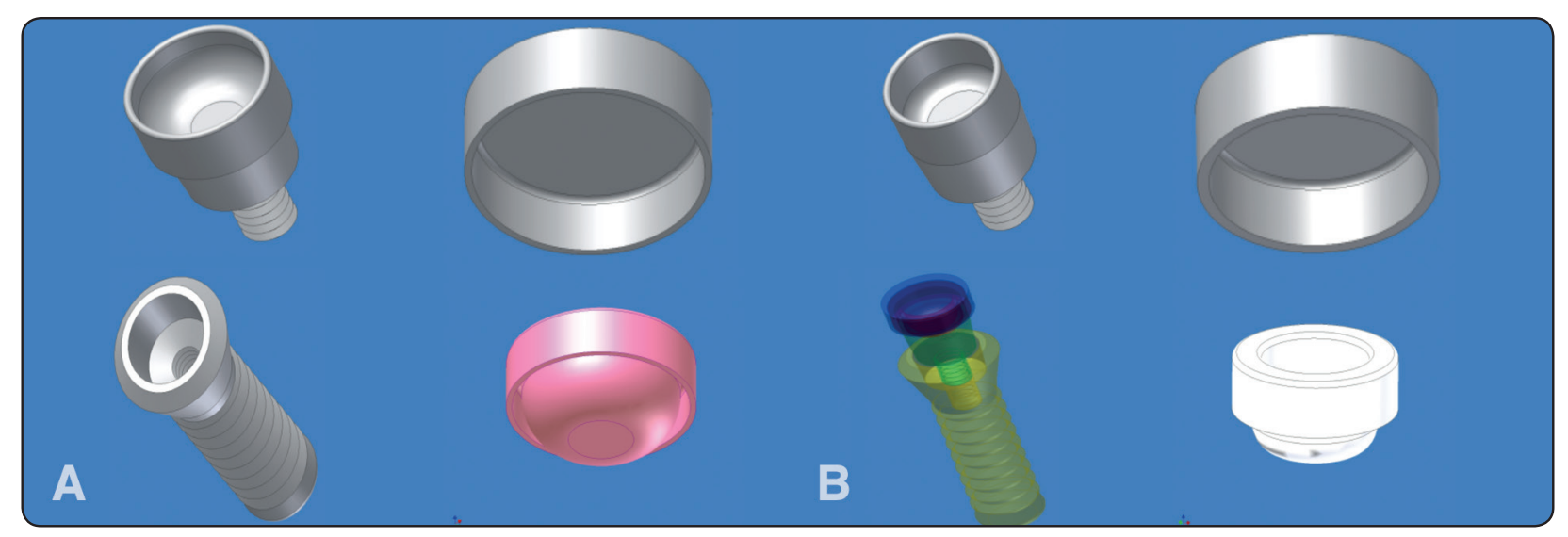

Fig. (1) Implant complex with (A) locator, and (B) Novaloc models on Autodesk Inventor screen 
The implants were placed perpendicular to the horizontal plane. Where, perfect osseointegration was assumed to be presented between implants and bone. All materials were assumed to be isotropic, homogenous and linearly elastic and its properties are listed in Table1.

TABLE (1) Material properties used in the finite element model

\begin{tabular}{|l|c|c|}
\hline \multicolumn{1}{|c|}{ Material } & $\begin{array}{c}\text { Young's } \\
\text { modules } \\
\text { [GPa] }\end{array}$ & $\begin{array}{c}\text { Posison's } \\
\text { ratio }\end{array}$ \\
\hline Overdenture & 2.70 & 0.35 \\
\hline Mucosa & 0.01 & 0.40 \\
\hline Resilient Cap - PEEK & 3.00 & 0.40 \\
- Nylon & 0.35 & 0.40 \\
\hline Implant (85\% Ti, 15\% Zr) & 125 & 0.34 \\
\hline Attachment (Titanium) & 110 & 0.35 \\
\hline Cortical bone & 13.7 & 0.30 \\
\hline Cancellaus (spongy) bone & 1.37 & 0.30 \\
\hline
\end{tabular}

Set of Boolean operations between the modeled components were performed before obtaining the complete model(s) assembled. Meshing of these components was done by 3D brick solid element "Solid-185" which has three degrees of freedom (translations in main axes directions) the resulted numbers of nodes and elements are listed in Table
2, and samples for these meshed components are presented as screen shots from ANSYS screen in Figure 2. The lowest plane of each model was considered as fixed nodes in the three directions as a boundary condition. Three loading conditions were tested for each model as $100 \mathrm{~N}$ vertically and $50 \mathrm{~N}$ oblique at $30^{\circ}$ and $45^{\circ}$ angle, where loads to be applied in the molar region.

Table 2: Number of nodes and elements in all meshed components

\begin{tabular}{|l|c|c|c|c|}
\hline & \multicolumn{2}{|c|}{$\begin{array}{r}\text { 2x Locator } \\
\text { Attachment }\end{array}$} & \multicolumn{2}{c|}{$\begin{array}{c}\text { 2x Novaloc } \\
\text { Attachment }\end{array}$} \\
\hline Component & Nodes & Elements & Nodes & Elements \\
\hline Overdenture & 7,611 & 8,789 & 7,821 & 8,947 \\
\hline Mucosa & 1,570 & 3,909 & 1,945 & 4,296 \\
\hline 2x Metal Housing & 1,601 & 3,330 & 1,840 & 3,721 \\
\hline 2x Nylon/PEEK Cap & 2,054 & 19,605 & 3,140 & 33,848 \\
\hline 2x Implant/Attachment & 17,178 & 134,276 & 20,669 & 165,122 \\
\hline Cortical bone & 1,200 & 3,808 & 1,132 & 3,790 \\
\hline Spongy bone & 1,764 & 24,201 & 1,760 & 24,167 \\
\hline
\end{tabular}

Linear static analysis was performed on a personal computer (Intel Core i7 processor, $2.4 \mathrm{GHz}, 6.0$ GB RAM), using commercial multipurpose finite element software package (ANSYS version 14.0), that results of these models were verified against similar studies ${ }^{27-29}$.

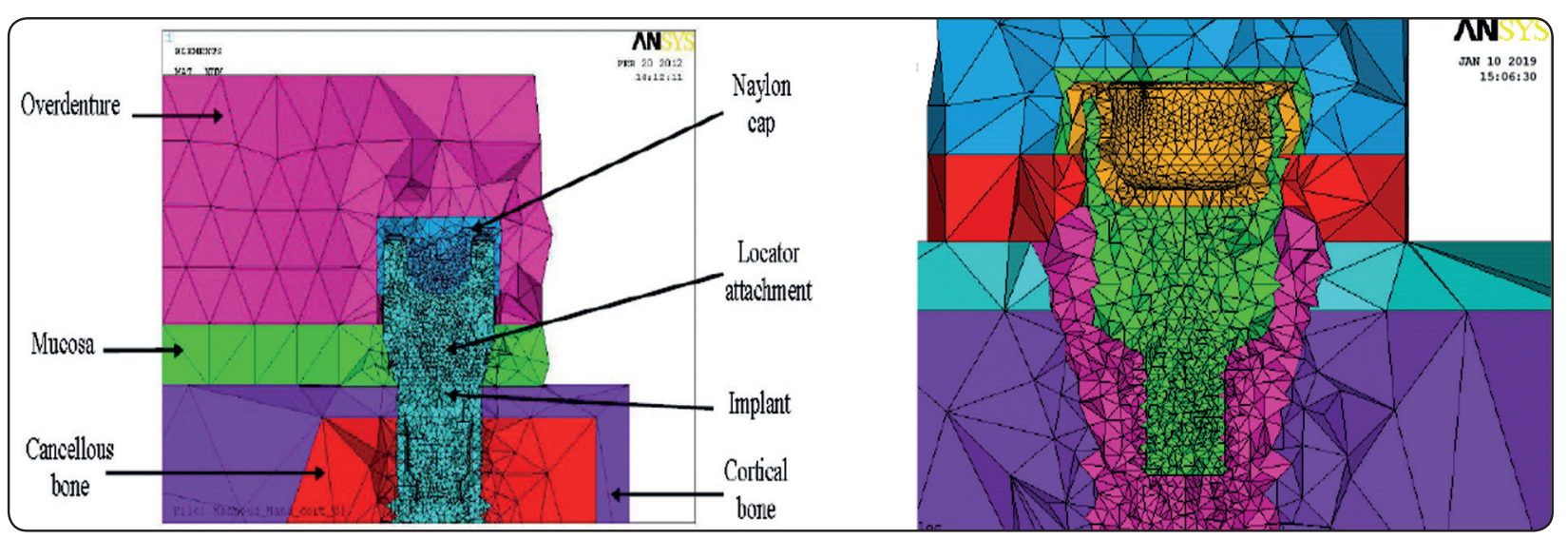

Fig. (2) Meshed components of the used models 


\section{RESULTS}

The locations and values of stresses under both vertical and oblique loading conditions were detected in the implant-abutment complex, cortical bone, cancellous bone, mucosa, resilient caps and prosthetic overdenture. All stresses and deformations appeared on all elements were within acceptable and physiological limits. Figure 3 demonstrates sample of components stresses on Locators attachment system under oblique load $\left(30^{\circ}\right)$ of $50 \mathrm{~N}$. While Figure 4 illustrates screen shots from finite element package for stress and deformation distributions on Novaloc attachment system under vertical load of $100 \mathrm{~N}$.

Although the value of oblique loading cases was about half the value of vertical loading cases it showed more sever stresses on bone.

Overdenture showed the maximum deformation and stresses around the applied load zone (molar area). It seems that the overdenture did not affected by changing attachment system from locator to Novaloc. While minor reduction (about 0.3 to 0.5 micron) in overdenture deformation was recorded with Novaloc system.

Generally mucosa was insensitive to attachment system.

Similar to cortical bone, spongy bone also received little more stresses with Novaloc system, where these values still within physiological limits (Figures 5 and 6).

Implant complex with Novaloc received more stresses in comparison to locators while all values were far from yield and endurance limits of Titanium.

Flexible caps behavior in both systems indicated its lifetime and maintenance periods estimation. PEEK caps with Novaloc system received less stresses when compared to nylon ones with locators system.

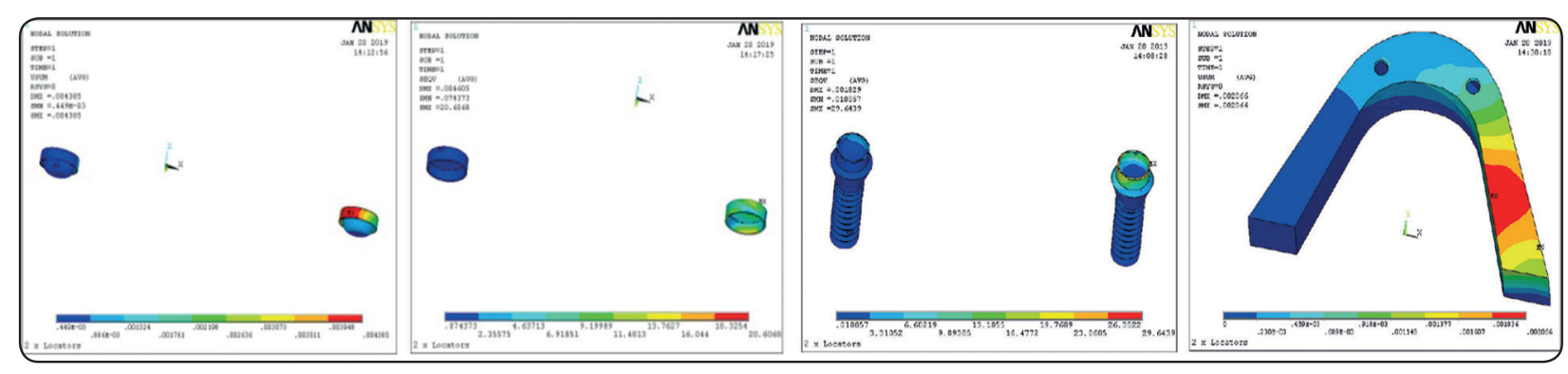

Fig. (3) Locators attachment system under oblique load $\left(30^{\circ}\right)$ of $50 \mathrm{~N}$

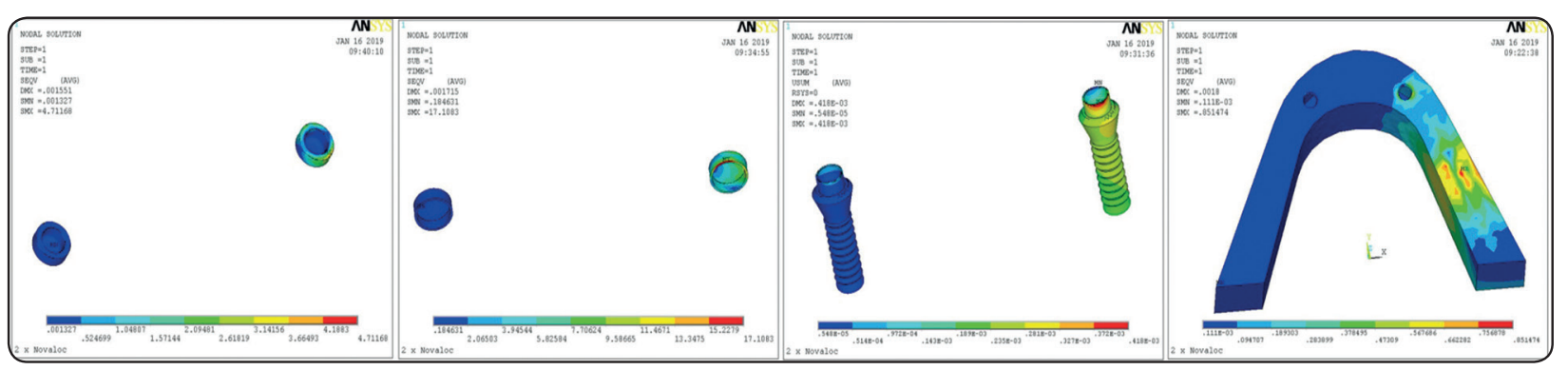

Fig. (4) Novaloc attachment system under vertical load of $100 \mathrm{~N}$ 


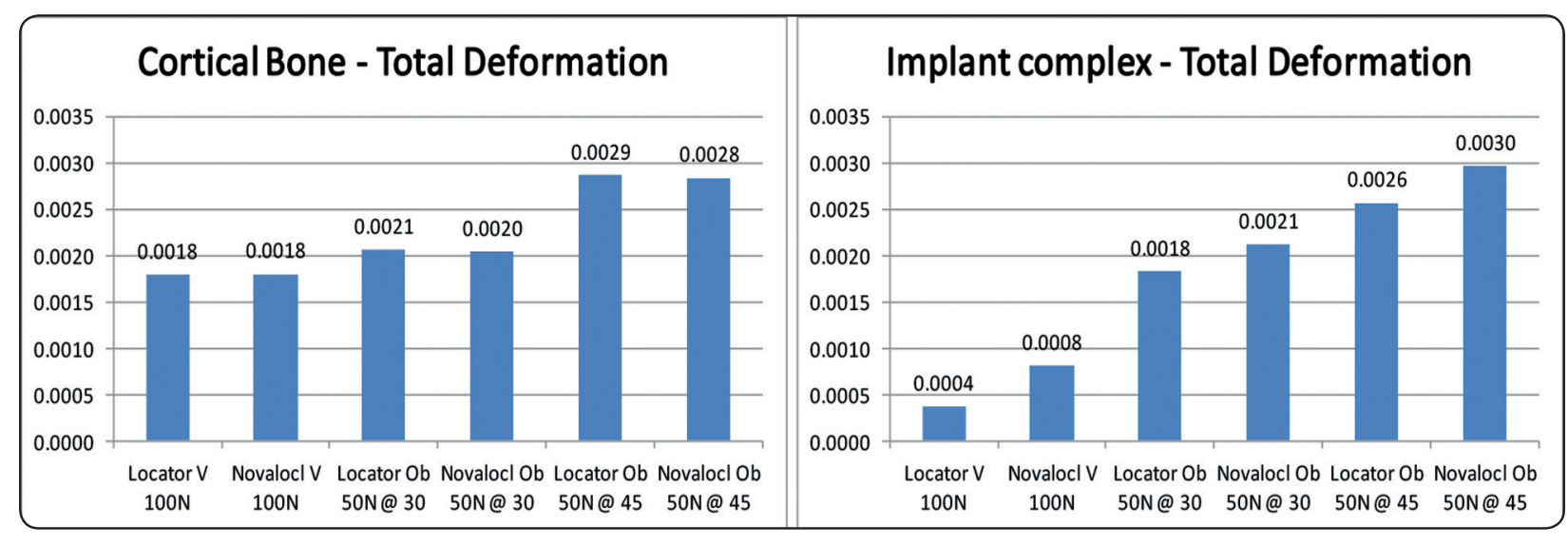

Fig. (5) Total deformation comparison

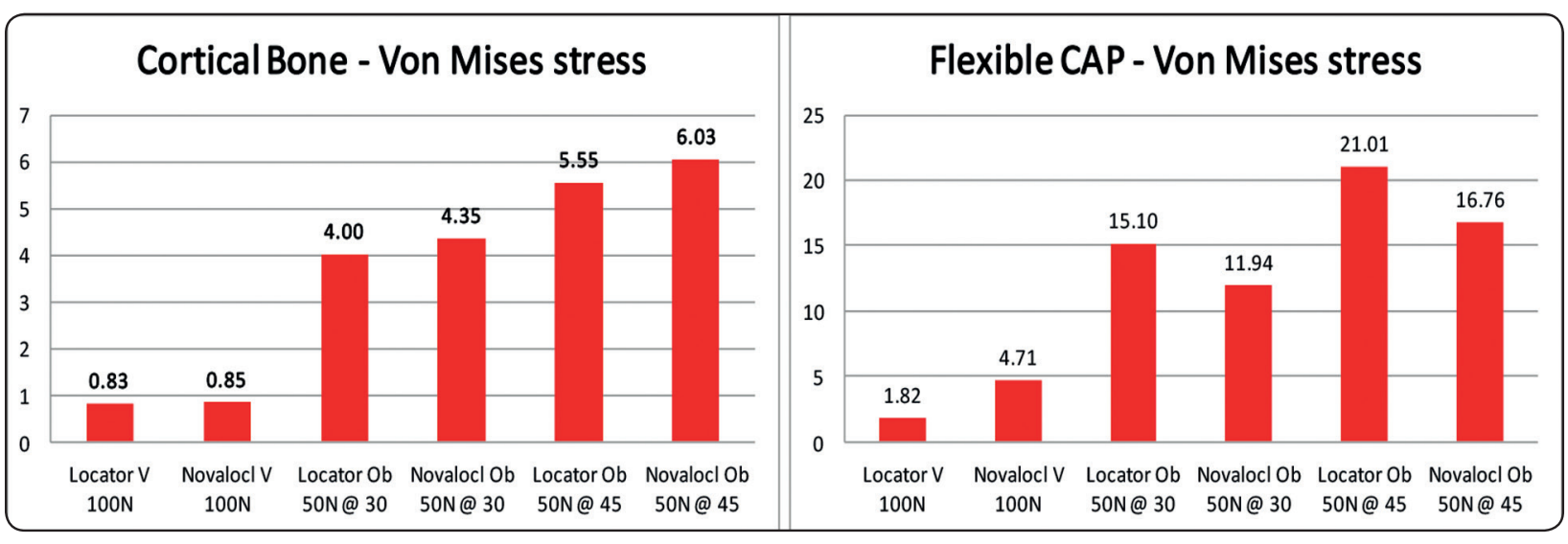

Fig. (6) Von Mises stress comparison

\section{DISCUSSION}

The results of this study showed that the Von Mises stresses generated by the application of vertical and oblique loads varied according to the type of attachment connected to the implant.

All stresses and deformations appeared on all elements were within acceptable and physiological limits. This is possibly related to the low profile design of the locator and Novaloc attachment which played a role in dissipating occlusal loads through the abutment to the implant fixture in a more favorable distribution and magnitude. Furthermore, the damping effect of the resilient cap in both attachments which tend to optimize stress distribution over the implants retaining the overdenture.21,37-39

The results of this study showed that bone (cortical and spongy) was in sensitive to change the attachment type. Similar result was noticed under vertical load for overdenture and mucosa, while a slight reduction in deformations were recorded by Novaloc attachment system. This may be attributed to the nearly similar geometric design of both attachments. Novaloc attachment deformed about 0.3 to 0.4 micron if compared to locator. Location of maximum deformation was the tip of the attachment towards the applied load. Such small deformation was referred to the increase in rigidity of the flexible 
cap, while reinforcing the abutment by the carbon coating could increase its hardness and resistance to wear.$^{21}$

Although the value of oblique loading conditions was about half that of vertical loading but it showed more sever stresses on bone with both attachments which came in corroboration with other studies ${ }^{40,41}$ who reported high bending stresses with lateral loading. Mucosa and overdenture were insensitive to changing attachment type.

On the other hand, about 8 to $10 \%$ more Von Mises stress was noticed on bone under oblique loading with using Novaloc system which was decreased to less than $1 \%$ under vertical loading, But generally all bone stresses values were within physiological limits. This difference could be attributed to the more rigid nature of the Novaloc PEEK matrix and the more retentive forces noticed with Novaloc attachment in comparison to the traditional locator attachment. ${ }^{21}$ This finding was in accordance with Takeshita et al ${ }^{42}$ who reported that the retentive forces of an attachment system influence stresses generated in the peri-implant bone during loading.

In the present study, Novaloc implant complex received about 50\% more Von Mises stress than locators one. However, these stresses were far away from yield point and endurance limit of Titanium which ensured lifetime usage of such systems without failure. In addition, metal housing with Novaloc system received from 5 to $25 \%$ more Von Mises stress, while it was within acceptable range for Titanium. This finding seems to be due to the cushion effect of the nylon cap of locator attachment, which tend to dissipate and absorb the induced stresses transmitted to the attachment implant complex than the more rigid PEEK matrix of Novaloc attachment.

Flexible caps were relaxed with Novaloc system under oblique loading, that it received less Von Mises stress by about $25 \%$ in comparison to locator system. The Von Mises stress value was doubled under vertical loading with Novaloc system if compared to locators. However, the yield strength of the PEEK material is much higher than that of locator nylon cap and could withstand these stresses. Accordingly, Longer flexible caps lifetime was expected for Novaloc system that means longer time between maintenance visits. These results are in line with Kleis et al, who reported a higher rate of maintenance for Locator systems in comparison to ball attachments in mandibular 2-implant overdentures and observed that the most frequent prosthetic complication of the locator attachments was the change of the plastic insert due to retention loss ${ }^{43}$.

\section{CONCLUSIONS}

Within the limitations of this in-vitro study it may be concluded that locator attachments may provide little less stress on the bone surrounding implants in implant retained overdenture than did the Novaloc attachment. However the lifetime of the flexible caps may be longer for Novaloc system in comparison to locator ones, that means longer time between maintenance visits.

Although the bone received about 8 to $10 \%$ more stresses with Novaloc system, the stress values were within physiological limits.

\section{ACKNOWLEDGEMENT}

Authors would like to express their deep thanks to Prf. Dr. Mohamed El-Anwar (Mechanical Engineering Dept,. National Research Centre) for their great effort during this study.

\section{ETHICAL APPROVAL}

This research doesn't require ethical approval and followed the Helsinki declaration.

The authors declare that they have no conflict of interest. 


\section{REFERENCES}

1- Amaral CF, Gomes RS, Rodrigues Garcia RCM, Del Bel Cury AA. Stress distribution of single-implant retained overdenture reinforced with a framework: A finite element analysis study. J Prosthet Dent, 2018; 19(5): 791-796

2- Salinas TJ. Implant prosthodontics. In: Miloro M, Ghali GE, Larsen PE, Waite PD, editors. Peterson's Principles of Oral and Maxillofacial Surgery $2^{\text {nd }} E d$, London: BC Decker, Inc Hamilton; 2004. p. 263.

3- Kutkut A, Bertoli E, Frazer R, Pinto-Sinai G, Fuentealba Hidalgo R, Studts J. A systematic review of studies comparing conventional complete denture and implant retained overdenture. J Prosthodont Res, 2018 ;62(1):1-9.

4- Meijer HJ, Raghoebar GM, Van 't Hof MA. Comparison of implant-retained mandibular overdentures and conventional complete dentures: A 10-year prospective study of clinical aspects and patient satisfaction. Int J Oral Maxillofac Implants 2003; 18:879-85

5- Meijer HJ, Raghoebar GM, Batenburg RH, Visser A, Vissink A. Mandibular overdentures supported by two or four endosseous implants: A 10-year clinical trial. Clin Oral Implants Res 2009; 20:722-8.

6- Cune M, Burgers M, van Kampen F, de Putter C, van der Bilt A. Mandibular overdentures retained by two implants: 10-year results from a crossover clinical trial comparing ball-socket and bar-clip attachments. Int $\mathrm{J}$ Prosthodont 2010; 23:310-315.

7- Feine JS, Carlsson GE, Awad MA, Chehade A, Duncan WJ, Gizani S, et al.The McGill consensus statement on overdentures. Mandibular two-implant overdentures as first choice standard of care for edentulous patients. Montreal, Quebec, 24-25, 2002. Int J Oral Maxillofac Implants 2002; 17:601-2.

8- Thomason JM, Feine J, Exley C, Moynihan P, Müller F, Naert I, et al. Mandibular two implant-supported overdentures as the first choice standard of care for edentulous. $\mathrm{Br}$ Dent J 2009;207 :185-6

9- Karthik K, Sivakumar Sivaraj, Thangaswamy V Evaluation of implant success: A review of past and present concepts. Journal of Pharmacy \& Bioallied Sciences . 2013; 5(1): 117-119.

10- Chiapasco M, Casentini P, Zaniboni M, Corsi E, Anello T. Titanium-zirconium alloy narrow-diameter implants (Straumann Roxolid(®)) for the rehabilitation of hori- zontally deficient edentulous ridges: prospective study on 18 consecutive patients. Clin Oral Implants Res. 2012;23 :1136-1141

11- Gottlow J, Dard M, Kjellson F, Obrecht M, Sennerby L. Evaluation of a new titanium-zirconium dental implant: a biomechanical and histological comparative study in the mini pig. J Clinic Implant Dent R. 2012; 14: 538-545

12- Bo Wen , Feng Zhu, Zhen Li, Peng Zhang, Xingnan Lin and Michel Dard. The osseointegration behavior of titanium-zirconium implants in ovariectomized rabbits. Clin Oral Implants Res. 2013;25: 21-27.

13- Barter S, Stone P, Brägger U.: A pilot study to evaluate the success and survival rate of titanium-zirconium implants in partially edentulous patients: results after 24 months of follow-up. Clin Oral Implants Res. 2012; 23(7):873-81

14- Cordeiro JM, Barao VA. Is there scientific evidence favoring the substitution of commercially pure titanium with titanium alloys for the manufacture of dental implants? Mater Sci Eng C Mater Biol Appl. 2017;71: 1201-1215.

15- Altuna P, Lucas-Taulé E, Gargallo-Albiol J, Figueras-Álvarez O, Hernández-Alfaro F, Nart J .Clinical evidence on titanium-zirconium dental implants: a systematic review and meta-analysis. Int J Oral Maxillofac Surg, 2016 ;45(7):842-50

16- Quirynen M, Al-Nawas B, Meijer HJ, Razavi A4, Reichert TE5, Schimmel M6, Storelli S, Romeo E. Small-diameter titanium Grade IV and titanium-zirconium implants in edentulous mandibles: Three-year results from a doubleblind, randomized controlled trial. Clin Oral Implants Res, 2015; 26(7):831-40

17- Al qutaibi AY. Attachments used with implant supported over denture. Adv Dent Oral Health. 2016;1(2):1-5

18- Kleis WK, Kammer PW, Hartmann S, Al-Nawas B, Wagner W. A comparison of three different attachment systems for mandibular two implant overdentures: One-year report. Clin Imp Dent Res. 2010; 12: 209-218.

19- Cordaro L, Di Torresanto VM, Petricevic N, Jornet PR, Torsello F. Single unit attachments improve peri-implant soft tissue conditions in mandibular overdentures supported by four implants. Clin Oral Impl Res. 2013; 24(5): 536-42.

20- Schneider AL. The use of a self-aligning, low-maintenance overdenture attachment. Dent Today. 2000; 19(4): 24-26.

21- Passia N, Ghazal M, Kern M. Long-term retention behaviour of resin matrix attachment systems for overdentures. J Mech Behav Biomed Mater. 2016;57:88-94. 
22- Sadowsky SJ, Caputo AA. Effect of anchorage system and extension base contact on load transfer with mandibular implant retained overdentures. J Prosthet Dent 2000 Sep;84(3):327-334.

23. Chun HJ, Park DN, Han CH, Heo SJ, Heo MS, Koak JY. Stress distribution in maxillary bone surrounding overdenture implants with different overdenture implants with different overdenture attachments. J Oral Rehabil 2005 ; 32(3): 193-205.

24- Mohammed SD, Desai H. Basic concepts of finite element analysis and its applications in dentistry: an overview. J Oral Hyg Health $2014 ; 2(5): 156$.

25- Daas M, Dubois G, Bonnet AS, Lipinski P, Rignon-Bret C. A complete finite element model of a mandibular implant retained overdenture with two implants: comparison between rigid and resilient attachment configurations. Med Eng Physics 2008 ;30(2):218-225

26- Savadi RC, Agarwal J, Agarwal RS, Rangarajan V. Influence of Implant Surface Topography and Loading Condition on Stress Distribution in Bone Around Implants: A Comparative 3D FEA. J Indian Prosthodont Soc. 2011;11:221-231

27- El-Anwar MI, Yousief SA, Soliman TA, Saleh MM, Omar WS. A Finite element study on stresses distribution of two different attachment designs under implant supported overdenture. Saudi Dent. J. 2015; 27(4):201-207.

28- El-Zawahry MM, Eman M. Ibraheem EM, Nassani MZ, Ghorab SA, EL-Anwar MI. Stress analysis of mandibular implant overdentures retained with one, two or four ball attachments: A finite element study. Dentl Res J. 2018 ; 15:437-443.

29- El-Anwar MI, El-Taftazany EA, Hamed HA, Abd ElHay MA. Influence of Number of Implants and Attachment Type on Stress Distribution in Mandibular Implant-Retained Overdentures: Finite Element Analysis. Open Access Maced J Med Sci. 2017; 5(2):244-249.

30- Prakash V, D’Souza M, Adhikari R. A comparison of stress distribution and flexion among various designs of bar attachments for implant overdentures: a three dimensional finite element analysis. Indian J Dent Res. 2009;20:31-36.

31- Tanino F, Hayakawa I, Hirano S, Minakuchi S. Finite element analysis of stress-breaking attachments on maxillary implant-retained overdentures. Int J Prosthodont. 2007; 20:193-198.

32- Bendjaballah MZ. The effect of non-contact conditions in a splinted fixed partial denture on the load sharing mechanism: a finite element study. J Bionic Eng. 2012;9: 336-342.

33- Barão VA, Assunção WG, Tabata LF, Delben JA, Gomes EA, de Sousa EA, Rocha EP.Finite element analysis to compare complete denture and implant-retained overdentures with different attachment systems. J Craniofac Surg. 2009; 20: 1066-1071

34- Vafaei F, Khoshhal M, Bayat-Movahed S, Ahangary AH, Firooz F, Izady A, Rakhshan V. Comparative stress distribution of implant-retained mandibular ball-supported and bar-supported overlay dentures: a finite element analysis. J Oral Implantol. 2011;37: 421-429

35- Abdelhamid AM, Assaad NK, Neena AF .Three Dimensional Finite Element Analysis to Evaluate Stress Distribution around Implant Retained Mandibular Overdenture Using Two Different Attachment Systems. J Dent Health Oral Disord Ther, 2015; 2(5): 00065

36- Mohamed I. El-Anwar and Mohamed S. Mohammed. Comparison between two low profile attachments for implant mandibular overdentures. Journal of Genetic Engineering and Biotechnology.2014;12:45-53

37- Kurtzman GM. The locator attachment: Free standing versus bar overdentures. Dent Labor Int plus. 2009; 1(1):2023. 25 .

38- Evtimovska E, Masri R, Driscoll CF, Romberg E. The change in retentive values of locator attachments and hader clips over time. J Prosthodont. 2009; 18(6):479-483.

39- Jain S, Jain D, Kumar A (2011) Comparative evaluation of stress in canine retained mandibular overdentures with three attachment designs - A 3D finite element analysis. JIDA 5: 791-793.

40- Muntianu LAS. Analyze of the mechanical stress distribution over implants in mandibular overdenture. Metalurgia Int. 2010; 15(3):24-26.

41- Tada S, Stegaroiu R, Kitamura E, Miyakawa O, Kusakari $H$. Influence of implant design and bone quality on stress/strain distribution in bone around implants: a three dimensional Finite Element Analysis. Int J Oral Maxillofac Imp. 2003 ; 18:357-368.

42- Takeshita S, Kanazawa M, Minakuchi S. Stress analysis of mandibular two-implant overdenture with different attachment systems. Dent Mater J. 2011; 30 (6):928-934.

43- Kleis WK, Kammerer PW, Hartmann S, Al-Nawas B, Wagner W. A comparison of three different attachment systems for mandibular two-implant overdentures: oneyear report. Clin Implant Dent Relat Res. 2010; 12(3):209218 